U.D.C. 314.174:332.1

key words: human capital, capital health, capital formation, gender analysis

E. V. Bazueva

\title{
THE HUMAN CAPITAL OF THE PERM REGION: GENDER PECULIARITIES OF REALIZATION
}

The necessity of application of research methodology in the capacity of criterion of analysing the strategy targets of regional development on the territory of Constituent Entities of the Russian Federation has been substantiated in the article. The strategy targets are worked out considering millennium development goals which have been stated. Analyzing the situation in the Perm region, gender peculiarities of human capital realization have been stated as the major factor of sustainable development of the post-industrial economy. The expenses for ineffective usage of health and education capital have been determined because most men and women in the Perm region ineffectively use health and education capitals on the grounds that male and female forms of development differ: low economic efficiency concerning human capital is typical for women as there is gender discrimination both in social and reproductive sectors of the regional economy. As a result of short life period and a great number of deaths at productive age most men use the human capital incompletely. It has been pointed out that such gender disbalance lessens the efficiency of functioning of the economic entities of the Perm region such as men and women, enterprises and institutions and regional economy in general. The ways of optimizing the usage of the men and women human capital in the economy of the Perm region have been suggested.

In September 2000, at the UN Millennium Summit, heads of 147 States, including Russia, adopted the Millennium Declaration to outline the following eight Development Goals: 1) to eradicate extreme poverty and hunger; 2 ) to achieve universal primary education; 3 ) to promote gender equality and to empower women; 4) to reduce child mortality; 5) to improve maternal health; 6) to combat HIV/AIDS, malaria and other diseases; 7) to ensure environmental sustainability; 8) to develop global partnership for development. All those goals are aimed at improving quantitative and qualitative parameters of human resources being the main factor of sustainable development of the modern society, which, according to the forwardlooking international opinion, should be based on the humanistic type of economic growth. Its preconditions include: a) combating the scarcity of natural resources based on a new scientific and technological revolution; b) combating social inequality (including gender inequality - author's comment), which hinders development of anyone's creative abilities [25, p.143]. We have made the above comment on purpose, since gender stereotypes, as one of the social inequality types, are also known to hinder 'human development'. A similar opinion was recognized at the international level by awarding, in 1998, the Nobel Prize in Economics to A. Sen for his contribution to the analysis of major factors working in the contemporary development, expansion of freedom being the main one of them. "Development means overcoming different types of lack of freedom (including gender freedom) that leave people with a poor choice and scares chances for fulfilling their intellectual activity" [26, p.16].

The above-mentioned world development goals should be incorporated into development strategies of all the countries that have accepted the Millennium Declaration. In this connection, Russia is now realizing the UNDP Project to provide support in achieving the Millennium Development Goals. UNDP experts have outlined some obligatory requirements for task-posing: 1) adapt tasks to the current development level of the region; 2) track tendencies with breaking down by gender and ethnic background. The latter means that gender-oriented research must become one of the cross criteria in analyzing indicators determined as targets for each area.

Within the framework of this Project, last year the first Report on Human Potential in the Perm region in 2009 was prepared. It was discussed on 24 November 2009 among the UNDP experts, the Moscow State University scientists, Director for regional programmes of the Independent Institute of Social Policy, the Perm region scientific and business people. The experts commented on the prevalence of economic aspects in the regional development to the prejudice of the proclaimed social goals, and lack of gender factor as a thorough criterion in analyzing indicators for each target area. The latter obviously conflicts with the main requirements set by the UNDP experts for task-posing in compliance with the Millennium Development Goals. Besides, this doesn't let us identify the existing limitations for 
Life Expectancy at Birth in the Perm region for 2000-2009, years

\begin{tabular}{|l|c|c|c|c|c|c|}
\hline Demographic Groups by Settlement Type & $\mathbf{2 0 0 0}$ & $\mathbf{2 0 0 3}$ & $\mathbf{2 0 0 5}$ & $\mathbf{2 0 0 7}$ & $\mathbf{2 0 0 8}$ & $\mathbf{2 0 0 9}^{\text {***|}}$ \\
\hline All population & 63,7 & 62,0 & 62,3 & 65,2 & 66,0 & 66,0 \\
\hline men & 57,6 & 55,7 & 55,7 & 58,8 & 59,6 & 59,0 \\
\hline women & 70,9 & 69,3 & 69,9 & 72,0 & 73,0 & 72,0 \\
\hline Urban population & 64,0 & 63,0 & 63,0 & 66,0 & 67,0 & 66,0 \\
\hline men & 57,0 & 56,0 & 57,0 & 60,0 & 61,0 & 60,0 \\
\hline women & 71,0 & 70,0 & 71,0 & 73,0 & 73,0 & 73,0 \\
\hline Rural population & 61,0 & 59,0 & 59,0 & 62,0 & 66,0 & 67,0 \\
\hline men & 55,0 & 53,0 & 53,0 & 56,0 & 56,0 & 60,0 \\
\hline women & 69,0 & 67,0 & 67,0 & 70,0 & 70,0 & 73,0 \\
\hline
\end{tabular}

* Based on: Permsky Krai. Stat.Ezhednevnik: Stat. Sbornik. Perm: Territorialnyi organ federalnoy statistiki po Permskomu krayu. 2009 [Elektronnyi resurs]. URL: htpp://permstat.gks.ru//public/webpages/Статистический\%20ежегодник\%20Пермского\%20 края.aspx (data obrascheniya: 09.04.2010) [The Perm region. Statistical Yearbook: Statistics Digest. Perm: Federal Statistics Local Agency for The Perm region. 2009 [Electronic library]. URL: htpp://permstat.gks.ru//public/webpages/Статистический\%20ежегодник\%20Пермского\%20края.aspx (date of reference: 09.04.2010)]

${ }^{* *}$ For 2009 estimated data is provided.

realizing the human potential of men and women in the region, which undoubtedly lowers efficiency of use of the main resources of the postindustrial economy ${ }^{1}$. All the above said proves that it is of current importance to make a thorough gender analysis of the specifics of using the human assets in the Perm region. This article will focus only on its two main elements: health capital and education capital.

We would like to remind that the main integral indicator, which describes the health capital of people, is life expectancy at birth. In the Perm region, as in Russia on the whole, there exists a considerable gender inequality, which is evidenced by table 1 .

The Table suggests the following conclusions. First, a considerably shorter lifetime is characteristic of both men and women in the Perm region as compared to people in developed countries. Thus, men live shorter by about 16.5 years and women by 4.9 years [11, p. 74]. We would like to note that such a considerable gender gap in the lifetime of men and women has not been observed in any other country of the world. In the Perm region, as in Russia on the whole, for the period under study, the gap has only slightly shortened, by 0.3 years. As a result, according to the demographic data, only every second man who reached his twentieth anniversary has a chance to survive to the retirement age. This situation results in unequal distribution of pension funds in favour of women, as women on pension live, on the average, 9 years longer than men (22.6) [4, p.138]. However, almost half of this difference is caused not by demographic reasons but by the

\footnotetext{
${ }^{1}$ For more details about costs of Russia's gender-asymmetrical economic development see: $[2,3,4,6,15,23,24]$
}

pension lifetime to working lifetime ratio. While for the Russian men this ratio is within the international "standard" of about $30 \%$, for the Russian women this indicator is one of the highest in the world $56 \%$. Thus, having compared a woman's lifetime on pension with her adult lifetime, we see that almost $40 \%$ of her adult life she lives on pension. As a result of the new pension formation procedure, the gender asymmetry will increase in the following directions: 1) the differentiation between men's and women's savings amounts will increase since women retire earlier; 2) the transfer of pension savings from men to women will increase since a uniform duration of the residual lifetime (19 years) is used in calculating pensions [4, p.138-141].

Second, lower lifetime indices are observed for both men and women living in rural areas, which undoubtedly results from the poor quality of the medical care, poor quality of their living conditions, frequent occurrence of behavioral risk factors. Thus, in the most depressive areas in Kudymkar and Yurlinsk regions of the Perm region (the territory of the former Komi-Permyatsky Autonomous District), men's life expectancy in 2008 was only 48.7 and 50.8 years, respectively [12]. Such a short lifetime of the Perm region people, especially men, is caused, on the one hand, by gender factors and people mortality structure; on the other hand, by inefficient healthcare system performance of the region making little contribution to enhancing the health capital of men and women in the Perm region.

Let's start with the analysis of gender differences in age-specific mortality of people in the region. The dynamics of age-specific death rates is shown in table 2.

The Table shows that the death rates of people at working age are high in the region. Moreover, they are 
Dynamics of Age-Specific Death Rates of Men and Women per 1,000 people of appropriate sex and age

\begin{tabular}{|c|c|c|c|c|c|c|c|c|c|c|}
\hline \multirow{2}{*}{ Age Groups } & \multicolumn{2}{|c|}{2000} & \multicolumn{2}{|c|}{2003} & \multicolumn{2}{|c|}{2005} & \multicolumn{2}{|c|}{2007} & \multicolumn{2}{|c|}{2008} \\
\hline & men & women & men & women & men & women & men & women & men & women \\
\hline infants under 1 year & 17,3 & 13,2 & 13,8 & 10,9 & 12,5 & 9,4 & 10,5 & 8,1 & 11,3 & 8,9 \\
\hline from 1 to 4 year & 1,1 & 0,9 & 1,0 & 0,7 & 0,8 & 0,7 & 0,7 & 0,5 & 0,7 & 0,7 \\
\hline from 5 to 9 year & 0,6 & 0,4 & 0,5 & 0,3 & 0,5 & 0,3 & 0,4 & 0,3 & 0,5 & 0,2 \\
\hline from 10 to 14 year & 0,6 & 0,3 & 0,6 & 0,3 & 0,5 & 0,3 & 0,5 & 0,3 & 0,5 & 0,2 \\
\hline from 15 to 19 year & 2,2 & 0,8 & 1,7 & 0,7 & 1,6 & 0,7 & 1,5 & 0,7 & 1,8 & 0,7 \\
\hline from 20 to 24 year & 5,0 & 1,2 & 3,9 & 1,0 & 3,8 & 1,0 & 3,2 & 0,9 & 3,6 & 1,0 \\
\hline from 25 to 29 year & 6,0 & 1,4 & 5,9 & 1,5 & 6,5 & 1,6 & 5,7 & 1,5 & 6,8 & 1,9 \\
\hline from 30 to 34 year & 7,0 & 1,8 & 7,5 & 2,1 & 8,2 & 2,2 & 7,4 & 2,0 & 9,2 & 2,5 \\
\hline from 35 to 39 year & 9,1 & 2,4 & 10,2 & 2,8 & 10,3 & 2,9 & 8,5 & 2,6 & 9,6 & 3,1 \\
\hline from 40 to 44 year & 12,6 & 3,4 & 14,4 & 4,0 & 14,3 & 4,0 & 11,4 & 3,3 & 12,7 & 3,7 \\
\hline from 45 to 49 year & 17,7 & 5,1 & 20,1 & 5,7 & 19,4 & 5,6 & 15,3 & 4,6 & 17,5 & 5,5 \\
\hline from 50 to 54 year & 24,4 & 7,6 & 27,9 & 8,6 & 26,9 & 8,1 & 21,3 & 6,6 & 24,3 & 7,5 \\
\hline from 55 to 59 year & 33,7 & 11,5 & 35,0 & 12,1 & 34,4 & 11,8 & 28,6 & 9,9 & 32,5 & 12,1 \\
\hline from 60 to 64 year & 45,0 & 15,9 & 49,7 & 17,3 & 46,9 & 16,5 & 39,1 & 13,7 & 44,5 & 15,9 \\
\hline from 65 to 69 year & 60,4 & 25,7 & 60,6 & 25,0 & 58,8 & 23,8 & 53,6 & 21,5 & 61,4 & 23,9 \\
\hline from 70 to 74 year & 81,5 & 41,0 & 84,1 & 42,2 & 80,5 & 39,4 & 71,7 & 34,9 & 82,6 & 37,3 \\
\hline from 75 to 79 year & 104,0 & 66,9 & 111,9 & 69,5 & 109,8 & 66,0 & 103,9 & 61,6 & 114,7 & 64,2 \\
\hline from 80 to 84 year & 146,0 & 112,7 & 149,0 & 114,0 & 139,2 & 107,0 & 134,3 & 103,0 & 165,5 & 106,1 \\
\hline 85 year and oldest & 201,0 & 207,9 & 246,1 & 230,0 & 226,7 & 221,0 & 202,1 & 204,0 & 246,2 & 214,9 \\
\hline
\end{tabular}

* Based on the data provided by the Federal Statistics Local Agency for the Perm region.

higher than the Russia's average rate. Thus, in 2007, the overall death rate among people of working age was $8.19 \%$ in the Perm region, while the Russia's average rate was $6.91 \%$. Besides, it is the working age where major differences between men and women mortality rates exist. Thus in 2007 , the death rates of men aged between 18 and 60 were $13.9 \%$, which is threefold death rates of women of the same age (3.9\%o) [12]. As noted by I.A. Kalabikhina, the mortality factor or the death cost influence in different age groups on formation of human capital is not the same for different sexes. Thus, the phenomenon of men supermortality at adult age increases the price of men capital reproduction since men who die at working age do not have time to "return" the human capital spent on their upbringing and education and to realize their accumulated individual capital [15]. In this connection, G. Becker noted that decrease in mortality of working age people would improve the prospect of getting earnings by extending the time during which one is able to do some paid job [5, p. 84]. Besides, the mortality of men aged 35 and older produces considerable gender disproportions in the men to women ratio. This results in narrower marriage markets for women, including markets for remarriage incident to these age groups, which further forming single-mother families, the percentage of which in the Perm region was $20 \%$ of the total number of families according to 2002 All-Russia Population Census. In our opinion, high mortality of men is caused by many reasons. For example, men more often stick to a health-wasting behaviour model (low self-protection behaviour, alcohol abuse, etc.). Table 3 shows the detail structure of mortality causes in the region.

The Table shows that circulatory illnesses stand first among mortality causes. This group of illnesses is considered to be age-dependent. However, though women outnumber men in older age groups, circulatory illness-caused mortality rates are practically identical for men and women. This means that men die of different illnesses at younger age. As reported by the Health Ministry specialists in The Perm region, infarctions and strokes have become more frequent among men aged between 30 and 40.

New growths are the second major cause of mortality of people in the Perm region, new growthcaused mortality of men being twice as high as the mortality rates of women.

Mortality due to external causes is also high in the region. This includes the so-called "accidental" death, which "comes generally as a result of breaking some regulated or common rules of conduct". Men die of this factor almost 4 times more often than women. It is no coincidence as major portions of the "accidental" death structure are occupied by "suicides", "attacks (homicides)", "accidental alcohol poisonings", "road traffic accidents", "other poisonings" [12].

It should be noted that the rates in all the categories of mortality causes in the Perm region, except for the 
People Mortality Cause Structure in The Perm region, per 100,000 people

\begin{tabular}{|l|c|c|c|c|c|c|c|c|}
\hline \multirow{2}{*}{ Mortality Cause Categories } & \multicolumn{2}{c|}{$\mathbf{2 0 0 0}$} & \multicolumn{2}{c|}{2005} & \multicolumn{2}{c|}{2007} & \multicolumn{2}{c|}{2008} \\
\cline { 2 - 9 } & men & women & men & women & men & women & men & women \\
\hline Died due to all causes & 2268,3 & 1146,3 & 2608,6 & 1193,2 & 2212,6 & 1043,3 & 2180,6 & 1013,0 \\
\hline including: & & & & & & & & \\
\hline infectious and parasitic diseases & 42,0 & 6,7 & 53,8 & 11,9 & 41,8 & 11,2 & 40,3 & 10,2 \\
\hline new growths & 295,6 & 136,9 & 291,0 & 135,3 & 282,9 & 131,8 & 287,7 & 133,5 \\
\hline circulatory illnesses & 1089,1 & 667,2 & 1319,3 & 707,1 & 1150,7 & 627,5 & 1135,2 & 618,1 \\
\hline respiratory illnesses & 150,9 & 39,4 & 170,7 & 35,9 & 121,6 & 29,0 & 123,4 & 25,0 \\
\hline digestive illnesses & 69,7 & 35,6 & 117,9 & 70,2 & 106,7 & 59,2 & 103,3 & 55,9 \\
\hline external causes & 469,9 & 133,4 & 492,2 & 127,3 & 400,8 & 101,1 & 386,0 & 94,1 \\
\hline
\end{tabular}

* Based on the data from $[7,8,9,10] /$

new growth-caused deaths, exceed Russia's average numbers. However, as pointed out by the experts, most deaths are controllable and therefore can be regarded as avoidable and may become an item of regional policy. For example, health resources of men and women in the Perm region are wasted greatly because of their employment in workplaces not complying with the sanitary and hygiene norms (table 4).

The number of men engaged in health-wasting workplaces in all industry sectors exceeds the number of employed women almost twice as much. This is typical of traditional Soviet-type employment standards, where harmful working conditions were considered to affect only a woman's organism lowering the quality of human capital of her children. However, due to the changes in the Labour Law, women can also work now at harmful workplaces, which is confirmed by the "positive" dynamics of their percentage among the people working in harmful working conditions in all industry sectors of the Perm region. This tendency is also observed for men engaged in health-wasting workplaces. However, the table contains only four industry sectors, which do not fully show the real amount of men's and women's health resources wasted in the regions of Russia. The occurrence rate of industrial injuries and occupational morbidity reflect the consequences of such employment (table 5).

The table shows that, in spite of the Safe Labour Program having been implemented in the Perm region since 2001, the level of fatal traumatism did not have any stable dynamics during the period under study, which once again confirms that employers are not interested in improving working conditions for men and women. Undoubtedly, the condition of equipment is crucial here. It is wellknown that the wear of fixed assets in the Perm region is over $50 \%$, which many times exceeds the allowable values. The above-said is also confirmed by lack of any stable dynamics in the occupational morbidity in the Perm region, as its main reason is

Table 4

Percentage of people engaged in harmful and hazardous working conditions, $\%$

\begin{tabular}{|l|c|c|c|c|c|c|}
\hline \multirow{2}{*}{\multicolumn{1}{|c|}{ Industry Sectors }} & \multicolumn{2}{c|}{$\mathbf{2 0 0 5}$} & \multicolumn{2}{c|}{$\mathbf{2 0 0 7}$} & \multicolumn{2}{c|}{$\mathbf{2 0 0 9}$} \\
\cline { 2 - 7 } & men & women & men & women & men & women \\
\hline Construction & 17,3 & 8,2 & 17,8 & 6,3 & 22,9 & 10,7 \\
\hline Mineral extraction & 27,3 & 10,0 & 29,8 & 10,6 & 40,5 & 19,8 \\
\hline Manufacturing & 37,3 & 22,4 & 42,5 & 28,4 & 46,6 & 30,1 \\
\hline $\begin{array}{l}\text { Production and distribution of } \\
\text { power, gas and water }\end{array}$ & 30,6 & 16,1 & 29,5 & 17,7 & 34,7 & 23,2 \\
\hline
\end{tabular}

* Made based on the data provided by the Federal Statistics Local Agency for The Perm region.

Table $5^{*}$

Dynamics of Industrial Injuries of Men and Women in the Perm region Industry in 2000-2009, people.

\begin{tabular}{|l|c|c|c|c|c|}
\hline \multicolumn{1}{|c|}{ Industrial Injuries Data } & $\mathbf{2 0 0 0}$ & $\mathbf{2 0 0 3}$ & $\mathbf{2 0 0 5}$ & $\mathbf{2 0 0 7}$ & $\mathbf{2 0 0 9}$ \\
\hline Men injured in industrial accidents & 3425 & 2235 & 1700 & 1448 & 980 \\
\hline Women injured in industrial accidents & 1021 & 827 & 617 & 569 & 409 \\
\hline Men injured in industrial accidents with fatal outcome & 103 & 90 & 68 & 85 & 53 \\
\hline Women injured in industrial accidents with fatal outcome & 3 & 7 & 10 & 4 & 5 \\
\hline
\end{tabular}

* Made based on the data provided by the Federal Statistics Local Agency for The Perm region. 
$86.6 \%$ the imperfection of technological processes and design deficiencies of equipment [12]. Men occupy over $2 / 3$ in the occupation morbidity structure in our region. This trend results from the fact that the greatest rates of occupational morbidity in 2008 were observed in traditionally "men's" activities: metallurgical industry, production of fuel minerals, machinery and equipment manufacturing and agriculture. Low efficiency of labour condition improvement programmes being implemented in the region has resulted in almost a quarter of men and women having occupational diseases and being not able to continue working in their profession and sometimes they even don't attain the pension age, especially men [12].

On the whole, even abriefanalysis of the men's and women's health evaluation shows that today health is not considered to be a strategic, productive resource in the industry of the Perm region, i.e. this resource is considered to be "priceless". Consequently, as noted by social sanitarian S. Tomilin as early as in the thirties of the 20th century, people are considered as natural good existing in abundance, and their health, as underlines academician V. Kaznacheyev, "is pumped out as gas from the subsoil" [16]. This is also confirmed by the health system funding model existing in Russia, which requires combined control of national health preservation: state (social component) and commercial (market component), i.e. agreement, in a required combination, of regulators and self-regulators of the medical service market. This healthcare model, as pointed out by N.S. Grigoryeva, does not ensure gender equality in the possibility to preserve health by the following criteria: 1) affordability /availability of medical care; 2) use by men and women of medical services in accordance with their real needs; 3) quality of medical service for men and women [6]. Table 5 shows social and market effects and anti-effects of the combined healthcare model in Russia, which is implemented in the Perm region, gender approach considered.

Considering the information in the table we can draw the following conclusions. First, women put more emphasis on the social efficiency of the public healthcare system performance; men value commercialization more, because they earn 40$50 \%$ more than women. So gender gap in incomes for men and women in the Perm region in 2007 was $37 \%$ [13].

Secondly, both women and men experience social and market anti-effects of modern public healthcare system performance. Social anti-effects are thought to be the following: 1) the compulsory health insurance $(\mathrm{CHI})$ basic programme is imbalanced in the volume of financial resources given by the government to the medical system; 2) dependence of free medical treatment quality on a place of living; it means that men and women living in a city and in the country have different opportunities in obtaining medical service under CHI. Up to now a unified system of medical service quality rating has not been worked out; 3 ) management structure of public healthcare is decentralized, as a result indirect price of the medical treatment increases, especially for women because of their lower social mobility.

Illegal money circulation in medical sphere is a clear illustration of the commercial ineffectiveness of the public healthcare system performance. Thus, on the one hand, patients without money are deprived of high-quality medical service, no taxes are paid, and public healthcare system lacks improvement. On the other hand, patients pay for the service twice tax payment and payment directly to health workers. Limited working hours of Medical and Preventive Treatment Department which is open during the patients' working hours do not help to solve this problem. As a result, both women and men have to pay twice for the medical services, for receiving this service without having to wait in a queue.

Moreover, voluntary medical insurance is not developed in public healthcare system, so there is no "feeding" commercial multiplier, which provides normal public healthcare system performance in the conditions of the social market [20].

We suppose that the optimisation process should be supported by additional investment in health from all economic entities, only in this case life prolongation for men and women in the Perm region would be possible. Here let us remind you the words of G. Becker "most deaths (if not all of them) are to some extent suicides - in a sense that these deaths could have been postponed, if more resources had been invested in life prolongation by the state, enterprises and the citizens themselves" $[5$, p. 3839]. Evaluation of investment profitability in men and women health capital is given in table $6^{1}$.

Thus, health investment appears to be very profitable for all economic entities, where men receive more feedback from self-protected behaviour than women. For example, disease will surely lead to salary reduction by $27.7 \%$ for men and $42 \%$ for women; annual earnings will drop by $19 \%$ for men and $27.7 \%$ for women [24].

Now let us consider the use efficiency of another intangible assert of the regional wealth - education capital of men and women in the Perm region. We will begin with the gender analysis of demand in

\footnotetext{
${ }^{1}$ See here for more details [1].
} 
Table 6

Social and Market Criteria of Medical Service Availability and Quality in the Combined Health Model in Russia at the beginning of the $21^{\text {st }}$ Century

\begin{tabular}{|c|c|c|c|c|}
\hline \multirow{3}{*}{ Criteria } & \multicolumn{4}{|c|}{ Alternative Evaluations of the Existing Healthcare Model } \\
\hline & \multicolumn{2}{|c|}{ Social Effectiveness (Non-Effectiveness) } & \multicolumn{2}{|c|}{ Commercial Efficiency (Inefficiency) } \\
\hline & $\begin{array}{l}\text { for the whole } \\
\text { population }\end{array}$ & gender peculiarities considered & $\begin{array}{c}\text { for the whole } \\
\text { population }\end{array}$ & gender peculiarities considered \\
\hline \multicolumn{5}{|c|}{ Group I- quantitative criteria } \\
\hline $\begin{array}{l}\text { Availability } \\
\text { of medical } \\
\text { care and } \\
\text { medical } \\
\text { services }\end{array}$ & $\begin{array}{l}\text { Free for people, } \\
\text { covered by the } \\
\text { Compulsory } \\
\text { Health } \\
\text { Insurance } \\
\text { System (CHI) }\end{array}$ & $\begin{array}{l}\text { Influenced by gender stereotypes, } \\
\text { major consumers of medical } \\
\text { services are women. However } \\
\text { their accessibility within the CHI } \\
\text { Programme to women is more } \\
\text { limited as it has been observed that } \\
\text { the poorer consumers are, the more } \\
\text { problems they have receiving medical } \\
\text { services [21] }\end{array}$ & To be paid by people & $\begin{array}{l}\text { Less affordable for women as } \\
\text { their earnings are lower as a } \\
\text { result of the existing differences } \\
\text { in earnings in labour market }\end{array}$ \\
\hline $\begin{array}{l}\text { Spectrum } \\
\text { of provided } \\
\text { services }\end{array}$ & $\begin{array}{l}\text { Limited } \\
\text { to the free } \\
\text { medical care } \\
\text { programme and } \\
\text { patient's place } \\
\text { of living }\end{array}$ & $\begin{array}{l}\text { Does not consider men's specific } \\
\text { problems: no well-developed } \\
\text { andrologist services, no specialized } \\
\text { psychological centers for men. }\end{array}$ & $\begin{array}{l}\text { Limited by the } \\
\text { amount of earning } \\
\text { of patients and their } \\
\text { families and by } \\
\text { influence of gender } \\
\text { role norms and social } \\
\text { environment }\end{array}$ & $\begin{array}{l}\text { Expenses for purchasing private } \\
\text { medical services are } 10-12 \% \\
\text { higher with men than with } \\
\text { women [2, p. 128] } \\
\text { With the restructured forms } \\
\text { of medical servicing, women } \\
\text { have more household load } \\
\text { as the amount of nonpaid } \\
\text { work done by women to treat } \\
\text { and attend their sick family } \\
\text { members increases, while the } \\
\text { amount of women participation } \\
\text { in the primary industry sector } \\
\text { decreases [2,p.131] }\end{array}$ \\
\hline $\begin{array}{l}\text { Supply with } \\
\text { medicines }\end{array}$ & $\begin{array}{l}\text { Limited to } \\
\text { the amount of } \\
\text { special purpose } \\
\text { budget funding } \\
\text { of state patient } \\
\text { care institutions } \\
\text { and pharmacies } \\
\text { («social drugs») }\end{array}$ & $\begin{array}{l}\text { Women are more influenced by } \\
\text { medicalization. } \\
\text { Men seek medical care only in } \\
\text { case of a serious disease [19]. They } \\
\text { twice more often resort to strict } \\
\text { self-medication measures, which } \\
\text { mean voluntary abandonment of } \\
\text { professional medical care even in case } \\
\text { of a serious disease [18, p. 29]. }\end{array}$ & $\begin{array}{l}\text { Higher access by } \\
\text { better-off people to } \\
\text { medicines having } \\
\text { international } \\
\text { certificates }\end{array}$ & $\begin{array}{l}58 \% \text { of women from low- } \\
\text { income families can not afford } \\
\text { to buy prescribed medicines [14, } \\
\text { p.39] } \\
\text { Limited to the low level self- } \\
\text { preservation behaviour of men }\end{array}$ \\
\hline \multicolumn{5}{|c|}{ Group II - qualitative criteria } \\
\hline $\begin{array}{l}\text { Availability } \\
\text { of treatment } \\
\text { by } \\
\text { advanced } \\
\text { methods }\end{array}$ & $\begin{array}{l}\text { Have to } \\
\text { be treated } \\
\text { by "social" } \\
\text { methods } \\
\text { (which the state } \\
\text { provides to the } \\
\text { patient free of } \\
\text { charge) }\end{array}$ & $\begin{array}{l}\text { Limited due to the lack of } \\
\text { mechanisms in using allowances for } \\
\text { expensive high-tech medical care } \\
\text { within the Health Project. Their } \\
\text { development is more important for } \\
\text { women as lack of highly qualified } \\
\text { care in maternity welfare clinics and } \\
\text { in-patient hospitals is one of the } \\
\text { factors of high maternal mortality. }\end{array}$ & $\begin{array}{l}\text { Can choose expensive } \\
\text { high-tech methods }\end{array}$ & $\begin{array}{l}\text { A higher education level } \\
\text { of women allows them to } \\
\text { better understand medical } \\
\text { innovations. However, they are } \\
\text { not free to practice them as they } \\
\text { are discriminated at forming } \\
\text { and distributing income inside } \\
\text { the household }\end{array}$ \\
\hline $\begin{array}{l}\text { Patient's } \\
\text { freedom in } \\
\text { choosing a } \\
\text { doctor }\end{array}$ & $\begin{array}{l}\text { Little freedom } \\
\text { (medical } \\
\text { servicing is } \\
\text { organized } \\
\text { based on the } \\
\text { by-district } \\
\text { principle, } \\
\text { reception only } \\
\text { by previous } \\
\text { appointment) } \\
\end{array}$ & $\begin{array}{l}\text { As women are less mobile socially, } \\
\text { they have more problems with } \\
\text { the administrative barriers in the } \\
\text { healthcare system. } \\
\text { Double fee is provided for those who } \\
\text { want to jump the queue in receiving } \\
\text { medical services }\end{array}$ & $\begin{array}{l}\text { Much freedom } \\
\text { (a doctor of any } \\
\text { qualification can be } \\
\text { chosen on paid basis } \\
\text { without previous } \\
\text { appointment) }\end{array}$ & $\begin{array}{l}\text { Does not exist due to low } \\
\text { incomes of most men and } \\
\text { women and lack of any well- } \\
\text { developed system of voluntary } \\
\text { medical insurance. } \\
\text { Men tend to one-visit servicing } \\
\text { much more than women, which } \\
\text { worsens their self-evaluation of } \\
\text { health due to lack of succession } \\
\text { in finding and treating diseases } \\
\end{array}$ \\
\hline
\end{tabular}


Ending table 6

\begin{tabular}{|l|l|l|l|l|}
\hline & $\begin{array}{l}\text { Adequate to } \\
\text { the material } \\
\text { and technical } \\
\text { base and } \\
\text { qualification } \\
\text { Qf medical } \\
\text { personnel of } \\
\text { medical } \\
\text { services } \\
\text { institution }\end{array}$ & $\begin{array}{l}\text { Low, as Medical and Preventive } \\
\text { Treatment Departments do not have } \\
\text { any disease management }\end{array}$ & $\begin{array}{l}\text { Can be treated in } \\
\text { commercial clinics } \\
\text { and their departments } \\
\text { organized in the state } \\
\text { sector }\end{array}$ & $\begin{array}{l}\text { Mainly women use alternative } \\
\text { quality is not controlled by the } \\
\text { state, patient protection is low. } \\
\text { medine services not having } \\
\text { any state licenses (healers, } \\
\text { paranormalists, magicians), } \\
\text { though there doesn't exist any } \\
\text { proof of the efficiency of such } \\
\text { treatment methods [2, p. 132] }\end{array}$ \\
\hline
\end{tabular}

Note: Works by I. N. Novikova, T. L. Lepikhina have been used to compile this table [20].

Table 7

Evaluation of investment profitability in gender health capital in socially-oriented market economy

\begin{tabular}{|c|c|c|c|}
\hline $\begin{array}{l}\text { Economic } \\
\text { Units }\end{array}$ & $\begin{array}{c}\text { Effects } \\
\text { (investment efficiency) }\end{array}$ & $\begin{array}{c}\text { Antieffects } \\
\text { (underinvestment losses) }\end{array}$ & $\begin{array}{c}\text { Public healthcare system } \\
\text { modernisation mechanisms }\end{array}$ \\
\hline Region & $\begin{array}{l}\text { Social peace and tranquillity in } \\
\text { society } \\
\text { Expenditures optimization of } \\
\text { social finances and increase of } \\
\text { commercial sector in public } \\
\text { healthcare system } \\
\text { GRP(Gross Regional Product) } \\
\text { doubling resulting from greater } \\
\text { involvement of the citizens into its } \\
\text { creation } \\
\text { Depopulation coping by means of } \\
\text { exogenous death causes decrease } \\
\text { and birth rate increase } \\
\text { Increase of the human capital } \\
\text { reproduction quality in the region }\end{array}$ & $\begin{array}{l}\text { Increase of direct medical costs (sick-leave } \\
\text { certificate, clinical outpatient certificate, } \\
\text { emergency services) and the costs of social } \\
\text { help for patients with partial disability } \\
\text { Increase of the indirect costs: 1) GRP } \\
\text { decrease connected with the loss of } \\
\text { labour capacity due to decease, absence } \\
\text { at workplace and (or) labour productivity } \\
\text { decrease; 2) high level of inflation leading } \\
\text { to labour productivity decrease (A. } \\
\text { Smith); 3) economy regression and growth } \\
\text { of social tension and instability in society, } \\
\text { depopulation (A. Marshall) }\end{array}$ & $\begin{array}{l}\text { Development and approval } \\
\text { of the multipurpose long- } \\
\text { term programme «Health of } \\
\text { the Perm region Population» } \\
\text { which will consider gender } \\
\text { peculiarities } \\
\text { Foundation of the Health } \\
\text { Resources Evaluation } \\
\text { Institute, which goals are } \\
\text { to safe life and health of } \\
\text { the citizens, to identify the } \\
\text { standards and indicators of } \\
\text { the medical service quality } \\
\text { Development and } \\
\text { implementation of } \\
\text { evaluation methodology of } \\
\text { compensation for moral and } \\
\text { health injury }\end{array}$ \\
\hline Enterprises & $\begin{array}{l}\text { Increase of enterprise profitability } \\
\text { by means of labour productivity } \\
\text { increase } \\
\text { Implementation of modern } \\
\text { resource saving technologies, which } \\
\text { reduce production costs } \\
\text { Elimination of workplaces with } \\
\text { harmful labour conditions, that } \\
\text { could lead to the reduction in fines } \\
\text { and employees' compensations }\end{array}$ & $\begin{array}{l}\text { Labour productivity decrease and } \\
\text { enterprise profitability decrease } \\
\text { Increase of social conflicts among } \\
\text { employees, rapid turnover in staff } \\
\text { Low level of the regional enterprises } \\
\text { competitiveness in the world market due to } \\
\text { the lack of socially responsible mechanisms } \\
\text { of interaction with the employees }\end{array}$ & $\begin{array}{l}\text { Employers' encouraging } \\
\text { in the workplaces creation } \\
\text { complying with the sanitary } \\
\text { and hygiene norms } \\
\text { Fines and compensation } \\
\text { increase for the labour- and } \\
\text { health-wasting production } \\
\text { technologies implementation }\end{array}$ \\
\hline Individuals & $\begin{array}{l}\text { Increase in the time of one's human } \\
\text { capital use, increase of its efficiency } \\
\text { Increase in the range of professions } \\
\text { to be chosen }\end{array}$ & $\begin{array}{l}\text { Decrease of household total income } \\
\text { Increase of the leisure time marginal value } \\
\text { Decrease of the total efficiency from human } \\
\text { capital investment } \\
\text { Decrease in the range of professions to be } \\
\text { chosen }\end{array}$ & \multirow{3}{*}{$\begin{array}{l}\text { Foundation of Health } \\
\text { Expertise Institute which } \\
\text { goals are to identify health } \\
\text { risk production factors and } \\
\text { their control at different types } \\
\text { of enterprises and to develop } \\
\text { technologies for calculating } \\
\text { health rent in the employees } \\
\text { earnings } \\
\text { Promotion of healthy life style } \\
\text { and the importance of self- } \\
\text { protected behaviour strategies }\end{array}$} \\
\hline Women & $\begin{array}{l}\text { Matrimonial market stabilization } \\
\text { Family well-being growth }\end{array}$ & $\begin{array}{l}\text { Widowhood possibility increase } \\
\text { Matrimonial market limitations for } \\
\text { remarriages } \\
\text { Single-mother families formation }\end{array}$ & \\
\hline Men & $\begin{array}{l}\text { Health awareness increase } \\
\text { Family well-being growth }\end{array}$ & $\begin{array}{l}\text { Low level of efficiency of human capital } \\
\text { investment }\end{array}$ & \\
\hline
\end{tabular}

the market of educational services. To achieve this of education in the Perm region. This information is purpose we will analyse the dynamics in the number given in table $7^{1}$.

of men and women receiving education in the system

${ }^{1}$ The table does not provide information about initial vocational and postgraduate education as far as Federal Statistics Local 
Dynamics in the number of men and women receiving education, number of people

\begin{tabular}{|c|c|c|c|c|c|c|c|c|}
\hline \multirow{2}{*}{$\begin{array}{l}\text { Types of state } \\
\text { educational } \\
\text { institution }\end{array}$} & \multicolumn{2}{|c|}{$2000 / 2001$ school year } & \multicolumn{2}{|c|}{$2003 / 2004$ school year } & \multicolumn{2}{|c|}{$2006 / 2007$ school year } & \multicolumn{2}{|c|}{$2009 / 2010$ school year } \\
\hline & men & women & men & women & men & women & men & women \\
\hline pre-school education & 53549 & 60015 & 55173 & 59174 & 58241 & 63054 & 59992 & 64697 \\
\hline general education & 178406 & 174738 & 156275 & 151629 & 134692 & 131685 & 128268 & 126794 \\
\hline $\begin{array}{l}\text { vocational secondary } \\
\text { education }\end{array}$ & 33694 & 28730 & 32533 & 27315 & 30119 & 27968 & 23736 & 27732 \\
\hline higher education & 40153 & 25882 & 53477 & 34087 & 60832 & 37793 & 65596 & 40900 \\
\hline
\end{tabular}

* Based on the data from Federal Statistics Local Agency for The Perm region.

The table suggests the following conclusions. First of all, in the region in the period under study one can see a positive dynamics in the number of children attending pre-school educational institutions. On the one hand, this can be connected with the increase in the number of children as far as this is the period of children who were born in 1999-2000, the time of birth rate growth. On the other hand, in the Perm region pre-school education facility is permanently becoming more accessible, which is of high importance for the gender equality, because now women can realise their own human capital which is still valuable after returning from maternity leave. For instance, from 2000 to 2008 pre-school educational institutions (PEI) capacity increased from 89 to 114 seats. At the same time the demand in pre-school educational institutions service is not fully met. In 2008 this index was $75 \%$. In the region this problem is solved in the following directions: 1) new PEI construction; 2) getting back into the system of education earlier redesigned buildings of the kindergardens; 3) development of family education; 4) development of non-state sector of educational services [12].

In the region the latter two directions are realized through the pilot project "Allowance to Families with children aged from 1.5 to 5 not visiting Municipal Pre-School Educational Institutions". The goal of this project is to give families possibility to choose from different types of child socialization in a PEI or in a family and at the same time to be paid an allowance. What is more, a child may be given education not only by parents or close relatives, but also by governesses. We want to emphasis that this service is provided only for well-to-do families.

Secondly, most learners in the Perm region are pupils. However, in the region the number of learners in General Education Institutions for the last decade decreased by more than 98 thousand pupils, where this trend among girls was more intensive. For instance, from 2000 to 2009 the

Agency for the Perm region does not monitor the data on these levels of education. number of boys decreased by 47,944 pupils whereas the number of girls dropped by 50,138 pupils. The decrease in the number of school learners mainly resulted from the decrease in the number of pupils which was connected with the demographic trends at the beginning of the 1900s. Only after the school year of 2010-2011 the number of school learners will begin to grow.

Third, according to table 7 , since 2000 in the Perm region the demand for tertiary education has increased. It should be noted that the demand for vocational secondary education among girls is constantly decreasing whereas the same trend among boys in 2007 experienced a slight growth. The latter is determined by the strategic differences in providing vocational secondary education for girls and boys. For instance, in accordance with the research made by the Ministry of Education of the Perm region in 2007, for most male school graduates the main reasons of entering Vocational Secondary Educational Institutions (VSEI) were the possibility to choose an interesting specialisation, that later will guarantee stable income, and easy learning in comparison with a Higher Institution. In this case girls follow the strategy of forced demand as far as their reason for having chosen VSEI is failure to enter a Higher Institution. Besides, girls were traditionally taught mainly by so called feminised specialists (public healthcare system, service sector, pedagogics and education and so on), whereas boys had masculinised teachers (machinery and metal working, electrical engineering, automatic devices and their control). The data in table 9 support these statements.

Fourth, the biggest surplus for the 20002009 period was noticed in the system of Higher Professional Education (HPE) of the Perm region, where the number of students increased by 25,443 girls and 15,018 boys. This type of education is still the most attractive one for them. However, even here gender asymmetry in students' specialization could be observed. (See table 9).

The Table shows that gender asymmetry of labour market arises in the system of future personnel 
Gender Ratings of Specialisations in State VSEI and HPEI in the Perm region in 2007/2008 academic year

\begin{tabular}{|c|c|}
\hline VSEI & HPEI \\
\hline \multicolumn{2}{|c|}{ Feminised (women share is more than 55\%) } \\
\hline $\begin{array}{l}\text { social sciences }(100 \%) \\
\text { public healthcare service }(86.1 \%) \\
\text { service sector }(83.7 \%) \\
\text { economics and management }(82.3 \%) \\
\text { education and pedagogics }(79.8 \%) \\
\text { culture and arts }(76.0 \%) \\
\text { foodstuffs technology }(72.4 \%) \\
\text { chemical and biotechnologies }(60.2 \%)\end{array}$ & $\begin{array}{l}\text { social sciences }(85.6 \%) \\
\text { public healthcare service }(82.4 \%) \\
\text { education and pedagogics }(82.1 \%) \\
\text { forest resources reproduction and processing }(78.9 \%) \\
\text { culture and arts }(76.5 \%) \\
\text { foodstuffs and consumer goods technology }(74.5 \%) \\
\text { economics and management }(73.8 \%) \\
\text { humanities }(66.6 \%) \\
\text { natural sciences }(64.5 \%) \\
\text { geodesics and land development }(64.3 \%)\end{array}$ \\
\hline \multicolumn{2}{|c|}{ Masculinised (women share is less than 45\%) } \\
\hline $\begin{array}{l}\text { power production, power engineering, electrical } \\
\text { engineering }(6.1 \%) \\
\text { vehicles }(9.1 \%) \\
\text { aviation and space missiles }(12.8 \%) \\
\text { geology, natural resources exploration and } \\
\text { exploitation }(13.1 \%) \\
\text { marine engineering (13.7\%) } \\
\text { electronic technology, radio engineering and } \\
\text { telecommunication (15.6\%) } \\
\text { automatic devices and control }(20 \%) \\
\text { agriculture and fishery }(23.9 \%)\end{array}$ & $\begin{array}{l}\text { vehicles }(2.1 \%) \\
\text { marine engineering }(4.4 \%) \\
\text { electrical engineering }(12 \%) \\
\text { power production, power engineering, electrical engineering }(10.6 \%) \\
\text { electronic technology, radio engineering and telecommunication }(16.8 \%) \\
\text { aviation and space missiles }(17.7 \%) \\
\text { computer science and computer engineering }(17.5 \%) \\
\text { geology, natural resources exploration and exploitation }(18.8 \%)\end{array}$ \\
\hline $\begin{array}{l}\text { computer science and computer engineering } \\
(25.3 \%) \\
\text { geodesics and land development }(38.9 \%)\end{array}$ & $\begin{array}{l}\text { information security (19\%) } \\
\text { metallurgy, machinery and metal working }(24.7 \%) \\
\text { tool engineering and optical engineering }(26.9 \%) \\
\text { chemical and biotechnologies }(33.4 \%) \\
\text { physico-mathematical sciences }(36.1 \%) \\
\text { architecture and construction }(37.6 \%) \\
\text { automatic devices and control }(41.9 \%) \\
\text { life safety, environmental engineering and environment protection }(43.2 \%)\end{array}$ \\
\hline \multicolumn{2}{|c|}{ Gender neutral (women share is within the limits of 45-55\%) } \\
\hline $\begin{array}{l}\text { forest resources reproduction and processing } \\
(49.3 \%) \\
\text { tool engineering and optical engineering } \\
(53.4 \%)\end{array}$ & $\begin{array}{l}\text { service sector (46.4\%) } \\
\text { agriculture and fishery }(49.0 \%)\end{array}$ \\
\hline
\end{tabular}

Notice: the principle of table is alternative, that is feminised specialisations are grouped according to the descending principle (women share declines), masculinised specialisations are classified according to the ascending principle (women share increases).

* Based on the data from the Ministry of Education of The Perm region.

education, because from the very beginning men are taught at the high-income specialisations whereas low-income specializations are for women. As a result education capital efficiency of women is considerably lower than that of men. For instance, minimum periods of return of education investment ${ }^{1}$ in some specialisations are calculated to be the following ones:

\section{Feminised:}

- trade, food services, material an technical supply and distribution, semiproducts -3.8 years;

$$
\text { - education }-3.3 \text { years; }
$$

\footnotetext{
${ }^{1}$ Calculation is based on average monthly salary indices in the industry on condition that right after graduation a graduate has found a job.
}

- public Utility Service, nonproduction types of public services -2.5 years;

$$
\begin{aligned}
& \text { 2. Masculinised: } \\
& - \text { loans, finances and insurance }-1 \text { year; } \\
& - \text { means of transport }-1.5 \text { year; } \\
& - \text { construction }-2.2 \text { years. }
\end{aligned}
$$

Moreover, the problem of education investment efficiency for women and men deepens by the increase in the number of learners demanding full recovery of their expenses. For instance, in 2008 in the Perm region there were 18 HPE Institutions, including 11 State, 5 non-State and 2 State institutions of additional professional education [12]. It should be noted that non-state educational institutions of HPE provide students only with the specialisations in humanities where, as the Table 8 
shows, mainly females study. That is why women share in the overall number of students in nonstate higher educational institutions is considerably larger, moreover, it increases annually. For instance, according to the data by the Ministry of Education of the Perm region in 2007 in comparison with 2006 this share increased by $2.1 \%$ and became $74 \%$. So the conclusion is that women spend much more resources on education than men do, but the investment efficiency is much lower. What is more, the cause of the decrease in education investment efficiency is not only in gender asymmetry in the labour market. One should not forget about the quality of women education. Non-state higher educational institutions competitiveness is known to be rather low, because school graduates who have not been successful at entering the state HPE institutions study there. Moreover, resource quality (finance, personnel and equipment) of non-state higher educational institutions is considerably low in comparison with the state educational institutions.

It should be added that the existing gap between the Perm region economy needs in professionals and the system of their training mainly affects the so called female specialisations. In the end many women have to find a job not connected with their specialisation, that clearly decreases their education efficiency.

Generally speaking, as M. E. Baskakova notes, we could state, that nowadays men and women have different strategies of obtaining general education and training for the professional activity. More often than not women tend to get complete general education at a general secondary school whereas professional training is obtained by them at the highest level. As far as the men are concerned, they are aimed at receiving education in a different way: incomplete (post-basic) education at a general secondary school is followed by study at an institution of basic vocational education [3, p. 220]. We should emphasize that bearing the theory of human capital in mind this strategy helps men to receive an expansion in the returns on education investment in comparison with women, even though the level of this type of education is considered to be low (we mean, in the system of Russian education). Why does it happen so? We shall try to answer this question.

Here we should refer to G. Becker who differentiated two types of training: general and specific. General training is training aimed at practicing a wide range of skills and abilities which can be useful in the sphere of a particular profession at any enterprise. Specific training is connected with specialised knowledge to be used for professional improvement of the company's employees. According to this approach the employees pay for their general training on their own. G. Becker points out that "it is the trainees, not the firms, who would bear the cost of general training and profit form the return" [5, p. 56]. In case of specific training it will not be the main factor to increase the employee's salary in other working places. Thus, it is specific training that will be a unique company resource comprising its intellectual capital. We should note here that in practice many western firms start to evaluate their intellectual capital. For total cost estimate one uses Tobin's ratio as ration of company market price to the replacement price of its physical assets (buildings, constructions, inventory stocks) ${ }^{1}$. Evaluation of the company's intellectual capital was carried out for the first time in 1995 by a Sweden's Insurance Company Skandia AKF in its annual report to shareholders. Nowadays in knowledge-intensive firms being the base of a new economy, physical capital is not included into the company's value. It is the intellectual capital that is the key production factor ${ }^{2}$. So specific training is not only paid by the company, but it also provides employee's salary increase because "firms would collect the returns on such training in the form of larger profits resulting from higher productivity" [5, p. 67]. Consequently we can assume that men (bluecolour jobs are known to be rather widely spread among men) have lower level of education, but they specialise in a particular enterprise thus earning more in the labour market.

Summarising, we can say that strategies for obtaining education chosen by men and women not only add to the gender discrepancies in the labour market, in the investment turnover in one's own human capital, but also decrease women educational competitive advantages in comparison with men.

Thus, we have revealed gender differences in a relatively stable from "men and women equality in rights and possibilities" point of view sphere of education in post-industrial economy. These differences will show the gender asymmetry more clearly because "those, who, for one reason or another, are outside the professional education, form a group of outsiders who may be excluded from the society with high level of productive labour and effective capital" [17, p. 123]. In such a case one should develop some measures aimed

\footnotetext{
${ }^{1}$ Tobin's ration for most modern companies is within $5-10$, for knowledge-intensive firms this ration can reach some hundreds [11, p. 115].

${ }^{2}$ For instance, in 1995 company's Lotus value in the period of merging with IBM was $\$ 3.5$ billion whereas its material asserts valued only $\$ 230 \mathrm{mln}$ [11, p. 115].
} 
at mitigating these negative gender tendencies. Moreover, the measures should be carried out by all units participated in market relations, that is state, regions, firms and households (women and men). We believe that top priority strategies for increasing the educational competitiveness of both women and men could be developed in the following directions:

- state - first of all, innovations seeking in the field of education management including the development of concept of effective interactions of market and non-market regulations mechanisms; secondly, development of a set of measures aimed at mitigating the gender imbalance in the labour market which can provide equal investment returns on women and men education;

- regional - permanent modernisation of higher school in accordance with the world and state standards which will correspond to the socioeconomic development needs of the regions;

- firms' strategies include the following points: 1) participation in the government orders elaboration in the sphere of required for regional management bodies professions for the middle and long-term perspectives; 2) human capital effective management including due regard to gender methodology.

- gender strategies for women presuppose women educational potential activation taking into account not only their own human capital, but also their own abilities development with regard to employer's needs and socio-economic region development.

All in all, we should state that gender peculiarities understanding of human capital realisation in the Perm region should lead to the increase of effective usage of the main resource of post-industrial economy, and consequently it could provide competitive advantages to the region in comparison with other subjects of Russia where the role of gender in this millennium has not been fully recognized yet.

\section{References}

1. Bazueva E. V. Ekonomika Zdoroviya: neobkhodimost' vnedreniya v sovremennoi Rossii // Problemy sovremennoi ekonomiki. 2009. №1. s.381-387 [Health Economics: its relevancy in modern Russia // Problems of Modern Economics. 2009. №1. pp. 381-387].

2. Ballaeva E. A. Gendernyi analiz politiki $\mathrm{v}$ sfere zdravookhraneniya / Gendernyi kaleidoskop. Kurs lektsii. Pod obtch.red. M.M.Malyshevoi.M.:Academia, 2001. 360 s. [Gender Analysis of the Policy in the Public Healthcare System / Gender Kaleidoscope. Course of Lectures. Chief Editor M. M. Malysheva. M.: Academia, 2001. 360 p.].

3. Baskakova M. E. Muzhchiny i zhentchiny v systeme zdravookhraneniya // Gendernoe neravenstvo v sovremennoi Rossii skvoz' prizmu statistiki / Otv.red. i sostav. Baskakova M. E. M: Editorial URSS, 2004. 336 s. [Men and Women in the System of Education // Gender Inequality in Modern Russia in
Terms of Statistics / Chief Editor and Compiler Baskakova M. E. M: Editorial URSS, 2004. 336 p.].

4. Baskakova M. E., Baskakov V. N., Lelchuk A. L. Gendernye aspekty novoi rossiiskoi pensionnoi sistemy // Gendernoe ravenstvo: poiski resheniya starykh problem. M.: Mezhdunarodnaya organizatsiya truda. 162 s. [Gender Aspects of New Russian Pension System // Gender Equality: looking for old problems solutions. M.: International Labour Organization. 162 p.].

5. Becker G. Chelovecheskoe povedenie: ekonomicheskii podkhod. Per. s angl. M.:GU VShE, 2003. 672 s. [Economic Approach to Human Behaviour. Translated from English. M.: GU BShE, 2003. 672 p.].

6. Grigorieva N. S. Gendernye izmereniya zdravookhraneniya // Teoriya i metodologiya gendernykh issledovanii: kurs lektsii. M.: MTsGI, 2001. 416 s. [Gender Measurements in Public Healthcare System // Theory and methodology of Gender Researches: course of lectures. M. : MTsGI, 2001. 416 p.].

7. Demographicheskii ezhegodnik Rossii 2002: Stat. sbornik. Moskva: Rossiiskii komitet statistiki. 2002. [sait]. URL: http://www.gks.ru (data obratcheniya 12.11.2009). [Demographic Yearbook of Russia 2002: Statistics Collection. Moscow: Russian Statistics Committee. 2002. [web site]. URL: http://www.gks.ru (date of reference 12.11.2009)].

8. Demographicheskii ezhegodnik Rossii 2006: Stat. sbornik. Moskva: Rossiiskii komitet statistiki. 2006. [sait]. URL: http://www.gks.ru (data obratcheniya 12.11.2009). [Demographic Yearbook of Russia 2006: Statistics Collection. Moscow: Russian Statistics Committee. 2006. [web site]. URL: http://www.gks.ru (date of reference 12.11.2009)].

9. Demographicheskii ezhegodnik Rossii 2008: Stat. sbornik. Moskva: Rossiiskii komitet statistiki. 2008. [sait]. URL: http://www.gks.ru (data obratcheniya 12.11.2009). [Demographic Yearbook of Russia 2008: Statistics Collection. Moscow: Russian Statistics Committee. 2008. [web site]. URL: http://www.gks.ru (date of reference 12.11.2009)].

10. Demographicheskii ezhegodnik Rossii 2009: Stat. sbornik. Moskva: Rossiiskii komitet statistiki. 2006. [sait]. URL: http://www.gks.ru (data obratcheniya 09.04.2010). [Demographic Yearbook of Russia 2009: Statistics Collection. Moscow: Russian Statistics Committee.2009. [web site]. URL: http://www.gks.ru (date of reference 09.04.2010)].

11. Doklad o razvitii chelovecheskogo potenchiala $\mathrm{v}$ Rossiiskoi Federatsii 2004. Na puti k obtchestvu, osnovannomu na znaniyakh / Pod obtch. red. S.N.Bobyleva. M.:Ves' mir, 2004. $132 \mathrm{~s}$. [Report on human potential development in the Russian Federation 2004. On the way to the knowledge-based society / Chief Editor S.N. Bobylev. M.: Whole World, 2004. 132 p.].

12. Doklad o razvitii chelovecheskogo potentsiala $\mathrm{v}$ Permskom Krae v 2009 g. [Elektronnyi resurs]. URL: http:// blog59.ru/wp-content/themes/blog59 (data obratcheniya: 16.11.2009). [Report on human potential development in the Perm region in 2009 [Internet resource]. URL: http://blog59.ru/ wp-content/themes/blog59 (date of reference: 16.11.2009)].

13. Zhentchiny i muzhchiny Rossii. 2008: Stat.sb. M. Rosstat, 2009. 281 s. [Women and Men in Russia. 2008: Works Collection. M. Rosstat, 2009. 281 p.].

14. Ibragimova D., Krasilnikova M., Ovcharova L. Uchastie naseleniya $\mathrm{v}$ oplate meditsinskikh i obrazovatelnykh uslug // Monitoring obtchestvennogo mneniya. Ekonomicheskie i sotsialnye peremeny / VTsIOM, mart-aprel' 2000. №2. [Population Contribution into Medical and Educational Services Payment // Public Opinion Monitoring. Economic and Social Changes / VTsIOM, March-April 2000. №2.]. 
15. Kalabikhina I. E. Gendernyi factor v vosproizvodstve chelovecheskogo kapitala // Zhentchina, gender, kultura. M.:MTsGI, 1999. 368 s. [Gender Factor in Human Capital Reproduction // Woman, Gender, Culture. M.: MTsGI, 1999. 368 p.].

16. Klyshnikov V. Neskromnoe obayanie otsentchika zdoroviya Kashina // Meditsinskaya gazeta ot 7.12.2001. [Immodest Charm of Mr Kashin, Health Estimator // Medical Newspaper, 07.12.2001].

17. Kostyuk V. N. Teoriya evolyutsii i sotsialno-ekonomicheskie protsessy. M. 2004/ 176 s. [Evolution Theory and Socio-Economic Processes. M. , 2004. 176 p.].

18. Medik B. A., Osipov A. M. Vzaimodeistvie naseleniya s uchrezhdeniyami zdravookhraneniya $\mathrm{v}$ regione (po dannym sotsiologicheskogo monitoringa) // Zdravookhranenie v RF. 2006. №4. s.28-31. [Interaction of Citizens and Public Healthcare Bodies in the Region (based on data taken from sociological monitoring) // Public Healthcare Service in the Russian Federation. 2006. №4. pp. 28-31].

19. Nasarova I. B. Stili povedeniya patsientov vo vramya zabolevaniya // Zdravookhranenie. 1999. №12. [Patients' Behaviour During the Period of Illness // Public Healthcare Service. 1999. №12].

20. Novikova I. N. Lepikhina T.L. Kriterii sotsialnoi zhiznesposobnosti i rynochnoi konkurentnosposobnosti novoi modelizdravookhraneniyav regione// Konkurentnosposobnost' regionov: teoretiko-prikladnye aspekty / Pod red. Yu.K. Perskogo, N.Ya.Kalyuzhnovoi. M.:TEIS, 2003.419 s. [Criteria of social viability and market competitiveness of a new model of public healthcare service in the region // Regions Competitiveness: theoretical practical aspects / Editors Yu. K. Perskiy, N. Ya. Kalyuzhnova. M.: TEIS, 2003. 419 p.].

21. Panova L. V., Rusinova N. L. Neravenstva v dostupe $\mathrm{k}$ pervichnoi meditsinskoi pomotchi // Sotsiologicheskie isslegovaniya. 2004. №3. s.126-132. [Access Inequalities in Obtaining the First Medical Aid // Sociological Researches. 2004. №3. pp. 126-132].
22. Permsky Krai. Stat. Ezhednevnik: Stat. Sbornik. Perm: Territorialnyi organ federalnoy statistiki po Permskomu krayu. 2009 [Elektronnyi resurs]. URL: htpp://permstat.gks.ru//public/ webpages/Статистический\%20ежегодник\%20Пермского \%20края.aspx (data obrascheniya: 09.04.2010) [The Perm region. Statistics Yearbook: Works Collection. Perm: Federal Statistics Local Agency for The Perm region. 2009 [Internet resource]. URL: htpp://permstat.gks.ru//public/webpages/ Статистический\%20ежегодник\%20Пермского\%20края. aspx (date of reference: 09.04.2010)].

23. Rimashevskaya N. M. Gender i macroekonomika // Chelovek i reformy: Secrety vyzhivaniya. M.:RITs ISEPN, 2003. 392 s. [Gender and Macroeconomics // Citizen and Reforms: Secrets of Survival. M.: RITs ISEPN, 2003. 392 p.].

24. Roschin S. Yu., Kuzmich O. S. Zdorovie kak ekonomicheskoe blago: ego vliyanie na zarabotnyyu platu i zanyatost' [Electronnyi resurs]. URL: http://www.aspe.spb.ru/ reports/roshtin.doc (data obratcheniya: 25.11.2006). [Health as an Economic Benefit: its impact on the income and employment [Internet resource]. URL: http://www.aspe.spb.ru/reports/ roshtin.doc (date of reference: 25.11.2006)].

25. Semenko $V$. V. Metodologiya sovremennoi politicheskoi ekonomii // Ekonomicheskaya teoriya: istoki i perspectivy. M.:Ekonomicheskii fakultet MGU, TEIS, 2006. 999s. [Methodology of Modern Political Economy // Economics: its sources and perspectives. M.: Economics faculty of MSU, TEIS, 2006. 999 p.].

26. Sen A. Razvitie kak svoboda / Per. s. angl. pod red. R.M.Nureeva. M.:Novoe izdatelstvo, 2004. 432s. [Development as Freedom / Translated from English, Editor R. M. Nureeva. M.: Novoe Izdatelstvo, 2004. 432 p.].

27. Tikhomirov A. $V$. Otpravnye nachala ideologii reformirovaniya zdravookhrabebiya // Zdravookhranenie RF. 2006. №4. S.37-42. [The Beginnings of Public Healthcare Service Reforms Ideology // Public Healthcare Service of the Russian Federation. 2006. №4. pp. 37-42]. 